\title{
Investigation of the Effects of Using Gas Flare to Dry Tapioca (Kpokpo-Garri) at Gana Flow-Station in Agbarha,Delta State, Nigeria
}

\author{
K. Emumejaye \\ Science Laboratory Technology Department, Delta State Polytechnic, Ozoro,Nigeria
}

\begin{abstract}
Local women in the Niger Delta use oil companies' gas flare sites to dry a popular cassava base food, kpokpo-garri (tapioca).This work is on the investigation of the effects of using gas flare to dry tapioca in the Niger Delta region of Nigeria. Two samples of tapioca dried with gas flare at Gana flow station, Agbarha were analyzed using a Unican 929 atomic absorption spectrophotometer for the presence of hazardous heavy metals. $\mathrm{Fe}, \mathrm{Mn}, \mathrm{Pb}, \mathrm{Cd}$, Ni and $\mathrm{Zn}$ were found in the dried tapioca in quantities above WHO safe limits. These make the dried tapioca unsafe for consumption. There is therefore the need for alternative means such as sun or oven to dry tapioca.
\end{abstract}

Keywords: Tapioca, Flare, Gana, Flow- Station, Heavy metals

\section{Introduction}

Nigeria is a nation highly endowed with natural resources among which are oil and gas. According to Chijoke [1], Nigeria has an estimated 180 cubic feet of proven natural gas making it the ninth largest concentration in the world. About $75 \%$ of this volume is flared.

Gas flaring is the combustion of unutilized excess gas during oil exploration and exploitation which lead to the emission of carbon (IV) oxide, carbon (II) oxide, nitrogen (IV) oxide, hydrogen sulphide, sulphur (IV) oxide, soot, smoke, heavy metals like iron $(\mathrm{Fe})$, manganese $(\mathrm{Mn})$ copper $(\mathrm{Cu})$, cobalt $(\mathrm{Co})$, lead $(\mathrm{Pb})$ and chromium (Cr).

Local women in Niger delta use oil companies' gas flare sites to dry a popular cassava base food, kpokpo-garri (tapioca). While natural gas doesn't emit the same amount of greenhouse gases as their fossil fuel, it does release carbon contributing to global warming.

In addition, other gases such as sulphur (IV) oxide and nitrogen (IV) oxide released during flaring are principally responsible for acid rain which in turn cause damage to terrestrial ecosystem by increasing soil acidity, decreasing nutrient availability reduce the productivity of fresh water (fishes), defoliation of crops plant, acceleration corrosion of metals and roofing sheets amongst others [2].

Malfunctioning gas furnaces sometime emit poisonous carbon monoxide which if inhaled deprives people of necessary oxygen.

Hydrogen sulphide a colourless but very poisonous gas with a repulsive smell like that of a rotten egg is also released during flaring. Hydrogen sulphide in air often causes the change of colour of paint due to its reaction with a metallic pigment [3].

Lastly the black particulate matter (smoke) which is formed during incomplete combustion is accompanied by Smog. Both have dark and tiny physical characteristics which absorb sunlight and increase the temperature around the flaring zone [4].

\section{Health Effects of Using Gas Flaring in Processing Food}

The health impacts of gas flaring are already well-documented. They emit a range of toxins including mercury, benzene, lead, nitrogen oxide, sulphur, incidence of asthma, cancers and respiratory illness in children [5]. The chemical benzene is especially hazardous, causing leukemia and other blood-related disease. Women approaching the flare and people eating the processed food are especially at risk.

Women using gas flare to dry tapioca complain of rashes and itching, miscarriage, burns and case of continuous internal heat. Those who eat the processed tapioca suffer discomfort, stomach aches, discoloration and strong smell of chemical [6].

\section{Chemicals Produced in Flaring}

The development of oil and gas comes with a terrible cost in human health. The cost is not for the workers on site, though they are affected. It is to women and children, the aged and infirm, the teachers and doctors and pharmacists and priests and first nation people who live away from but in proximity to a place site. 
They live at home and are exposed where they sleep and eat as wind carries the plume of combustion product from the source to their residence as much as $30 \mathrm{~km}$ from any flare.

In his investigation of flare gas emission in Alberta (Canada) Strosher [6] established that the following chemicals are emitted in a gas flare.

Table 1: chemicals emitted from gas flare

\begin{tabular}{|l|l|}
\hline Chemical & Concentration $\left(\mathbf{m g} / \mathbf{m}^{\mathbf{s}}\right)$ \\
\hline 1) Hydrogen & 20.0 \\
\hline 2) Co & 15.7 \\
\hline 3) $\mathrm{Co}_{2}$ & 4890 \\
\hline 4) Carbon & 54.2 \\
\hline 5)methane & 103.8 \\
\hline 6) Ethylene & 29.0 \\
\hline 7) acetylene & 53.7 \\
\hline 8) Ethene & 11.7 \\
\hline 9) $\mathrm{C}_{3}$ Hc's & 11.7 \\
\hline 10) $\mathrm{C}_{4}$ Hc's & 6.4 \\
\hline 11) Benzene & 116.5 \\
\hline 12) Toluene & 18.2 \\
\hline 13) xylenes & 29.8 \\
\hline 14) Styrenes & 75.5 \\
\hline 15) Ethyny/benzene & 79.6 \\
\hline 16) Naphthalene & 77.2 \\
\hline 17) Other Hc's & 128.5 \\
\hline
\end{tabular}

Similarly, sonibare and Akeredolu [7] identified the following chemical in gas flare emission in UmutuEbedei in Niger Delta region of Nigeria.

Table 2: chemicals emitted from gas flare in the Niger - Delta region

\begin{tabular}{|l|l|}
\hline Chemical & Concentration $\left.\mathbf{( m g / \mathbf { d n } ^ { 3 }}\right)$ \\
\hline 1) Hydrogen & 19.9 \\
\hline 2) Co & 16.1 \\
\hline 3) $\mathrm{CO}_{2}$ & 5180 \\
\hline 4) Carbon & 46.5 \\
\hline 5) Methane & 115.5 \\
\hline 6) Acetylene & 60.4 \\
\hline 7) $\mathrm{C}_{3} \mathrm{Hc}$ 's & 12.1 \\
\hline 8) $\mathrm{C}_{4} \mathrm{Hc}$ 's & 5.4 \\
\hline 9) Benzene & 121.4 \\
\hline 10) Toluene & 19.4 \\
\hline 11) Xylenes & 30.5 \\
\hline 12) Styrene & 80.4 \\
\hline 13) Ethyny/benzene & 75.1 \\
\hline 14) Naphthalene & 80.1 \\
\hline 15) Other Hc's & 138.9 \\
\hline
\end{tabular}

The concentration of benzene, toluene, xylenes styrenes and naphthalene as identified in Umutu-Ebedei gas flare emissions are higher than those identified by Strosher in Alberta (Canada) gas flare emission. This may be the result of poorer technology and it means greater environmental pollution and health hazard of the use of gas flare in drying tapioca.

\section{Other Substances}

\section{- Dioxins}

Dioxins is the abbreviation for large close of persistent, long-lived and ubiquitous chemicals with the some basic structure, two benzene rings joined through two oxygen atoms [8]. An example is 2, 3, 7, 8 . Tetrachloro-dibenzodioxin (TCDD). Exposure to TCDD is well established as the cause of chloracne. This is a dermatological condition distinguished by the distribution of the lesion. The most sensitive areas are the face and behind the ears [9]. 


\section{- Particulates}

Strosher [6] describes particulate as carbon in the plume. These are both solid and colloidal micron-size particulate that are produced in open, uncontrolled burning. Inhaling these particulate is strongly involved with elevated rate of morbidity and morbidity from all cause, lung caner, heart disease and respiratory disease.

\section{Effects of Heavy Metals}

Heavy metals are metallic chemical elements that have relatively high density and toxic or poisonous at low concentration. Example of heavy metals that are harmful to humans includes cadmium, lead, nickel et.c

Chronic exposure to these metals can have serious health consequences. Humans are exposed to those heavy metals through inhalation of polluted air from gas flaring, consumption of contaminated drinking water or consumption of contaminated food.

Heavy metals exposure causes serious health effect including reduced growth and development, cancer, organ damage and in extreme cases, death [10].

Metals are particularly toxic to the sensitive, rapidly developing systems of fetuses, infants and young children some metals such as lead easily cross the placenta and damage the fetal brain. Childhood exposure to some metals can result in learning difficulties memory impairment, damage to the nervous system and behavioural problem such as aggressiveness and hyperactivity [11].

\section{Harmful Effects of Heavy Metals}

The harmful effects of the heavy metals as stated by idodo-Umeh [12] are as follows.

\begin{tabular}{|c|c|}
\hline Heavy metals & $\begin{array}{l}\text { (a) Excessive accumulation in the human body promotes bacterial growth as iron } \\
\text { is needed in their growth } \\
\text { (b) Cancer harmful effects }\end{array}$ \\
\hline 2. Manganese (Mn) & $\begin{array}{l}\text { (a) High levels of manganese cause gene mutation. } \\
\text { (b) It may also cause Parkinson disease. }\end{array}$ \\
\hline 3. Lead $(\mathrm{Pb})$ & $\begin{array}{l}\text { (a) Loss of appetite, nausea, abdominal cramps, anemia and weakness. } \\
\text { (b) Kidney infection (nephritis) } \\
\text { (c) Brain damage, mental deficiency leading to abnormal behaviour } \\
\text { (d) Lead in water combines with the mucus of the gill covers resulting in the } \\
\text { interference with normal respiration causing the death of fish by asphysciation } \\
\text { (suffocation). }\end{array}$ \\
\hline 4. Cadmium $(\mathrm{Cd})$ & $\begin{array}{l}\text { (a) High blood pressure } \\
\text { (b) Kidney and liver damage } \\
\text { (c) Destruction of testicular tissue and red blood cells } \\
\text { (d) Bronchitis } \\
\text { (e) Cancer } \\
\text { (f) Inactivated enzymes } \\
\text { (g) Abnormal swelling of the lungs } \\
\text { (h) Abdominal pains } \\
\text { (i) Nausea, anemia, vomiting dizziness and diarrhoea. }\end{array}$ \\
\hline 5. Nickel (Ni) & $\begin{array}{l}\text { (a) Liver cancer } \\
\text { (b) Kidney damage } \\
\text { (c) Asthma }\end{array}$ \\
\hline 6. Copper (cu) & $\begin{array}{l}\text { (a) Stomach and intestinal distress resulting in vomiting, diarrhoea, stomach } \\
\text { cramps. } \\
\text { (b) Liver disorder } \\
\text { (c) Water polluted with copper kills water plants and fish. }\end{array}$ \\
\hline 7. Zinc (zn) & $\begin{array}{l}\text { (a) Depress the immune system leading to the invasion of the body by diseases. } \\
\text { (b) Accelerates the growth of prostrate cancer and contribution to colon cancer. } \\
\text { (c) Nausea, vomiting, diarrhoea, stomach, poor muscle co-ordination, fatigue and } \\
\text { possible kidney failure. } \\
\text { (d) Toxic to plant at higher level. }\end{array}$ \\
\hline
\end{tabular}




\section{Collection of Samples}

\section{Materials and Methods}

Two samples of tapioca made from cassava planted in an area with minimal flare activities were collected in new cellophane bags. These samples were later divided into two parts each and a portion of each sample dried at Gana flow- station site in Agbarha, Ughelli just as the neighbouring women do.

\section{Preparation of Samples}

$1 \mathrm{~g}$ of the dried tapioca was soaked with a few drops of distilled water in a clean beaker. Then $5 \mathrm{ml}$ of $\mathrm{HNO}_{3}$ were added and left for 10 minutes in the fume cupboard. This help to breakdown the organic compound and release the metals, further digestion was done by heating the sample in a hot plate. It was then allowed to cool and made up to $50 \mathrm{ml}$ with distilled water.

This was filtered through filter paper and again made up to $80 \mathrm{ml}$ with distilled water in a $100 \mathrm{ml}$ volumetric flask. Then $20 \mathrm{ml} \mathrm{Hcl}$ was added to it and left on a hot plate.

\section{Apparatus and Materials}

Distilled water, HNO3 solution, HCL solution ,Beakers, 100ml volumetric flask, Weighing balance ,Hot plate, Fume cupboard ,Measuring cylinder ,Filter funnel, Retort stand ,Atomic absorption spectrophotometer ,Pipettes

\section{Methods}

Preparation of Blank Sample

Blank sample were prepared using the same procedure with deionized water instead of tapioca samples.

\section{Analysis of Sample}

Analysis of cd, zn, cu, pb, mn, Ni, and fe was carried out on the undried and dried tapioca samples with unican 929 atomic absorption spectrophotometer filter with solar software.

\section{Result}

\section{Result and Discussion}

The tables 1 and 2 show the concentration in $\mathrm{mg} / \mathrm{kg}$ of the heavy metals found in the sample of tapioca dried with heat from gas flare in Gana flow-station, Agbarha, Delta State, Nigeria.

Table 1 sample a1

\begin{tabular}{|l|l|l|l|l|l|l|l|}
\hline sample ID & $\mathrm{Fe}$ & $\mathrm{Mn}$ & $\mathrm{Pb}$ & $\mathrm{cd}$ & $\mathrm{Ni}$ & $\mathrm{cu}$ & $\mathrm{Zn}$ \\
\hline (i) & 14.45 & 28.90 & 14.30 & 0.10 & 0.85 & 6.65 & 11.40 \\
\hline (ii) & 13.15 & 24.35 & 26.20 & 0.35 & 1.05 & 6.05 & 8.22 \\
\hline
\end{tabular}

Table 2 sample b2

\begin{tabular}{|l|l|l|l|l|l|l|l|}
\hline sample ID & $\mathrm{Fe}$ & $\mathrm{Mn}$ & $\mathrm{Pb}$ & $\mathrm{cd}$ & $\mathrm{Ni}$ & $\mathrm{cu}$ & $\mathrm{Zn}$ \\
\hline (i) & 6.90 & 27.30 & 38.10 & 0.25 & 0.85 & 14.05 & 6.96 \\
\hline (ii) & 7.40 & 23.90 & 38.10 & 0.35 & 0.00 & 3.40 & 10.62 \\
\hline
\end{tabular}

The tables 3 and 4 show the concentration in $\mathrm{mg} / \mathrm{kg}$ of the heavy metals found in the sample of un- dried tapioca.

\begin{tabular}{|l|l|l|l|l|l|l|l|}
\hline sample ID & Fe & Mn & Pb & cd & Ni & cu & Zn \\
\hline (i) & 4.45 & 8.90 & 4.30 & 0.10 & 0.85 & 6.65 & 5.40 \\
\hline (ii) & 3.15 & 4.35 & 6.20 & 0.35 & 1.05 & 6.05 & 6.22 \\
\hline sample ID & Fe & Mn & Pb & cd & Ni & cu & Zn \\
\hline (i) & 5.90 & 7.31 & 8.15 & 0.25 & 0.85 & 14.05 & 6.96 \\
\hline (ii) & 6.41 & 8.92 & 8.10 & 0.35 & 0.45 & 3.40 & 8.62 \\
\hline
\end{tabular}

\section{Discussion}

According to Idodo Umeh [12], the recommended maximum acceptable limits of these poisonous chemicals in food (in $\mathrm{mg} / \mathrm{kg}$ ) are shown in Table 5 . 
Table 5 WHO Recommended Maximum Acceptable Limit In Food

\begin{tabular}{|l|l|}
\hline Heavy Metal & $\begin{array}{l}\text { WHO Recommended Maximum Acceptable Limit in } \\
\text { Food }(\mathbf{m g} / \mathbf{K g})\end{array}$ \\
\hline 1. Iron $(\mathrm{Fe})$ & $1-3$ \\
\hline 2. Manganese $(\mathrm{Mn})$ & $0.1-0.5$ \\
\hline 3. Lead $(\mathrm{Pb})$ & 2 \\
\hline 4. Cadmium $(\mathrm{Cd})$ & 2 \\
\hline 5. Nickel $(\mathrm{ni})$ & $0.5-0.6$ \\
\hline 6. Copper $(\mathrm{cu})$ & $1-3$ \\
\hline 7. Zinc $(\mathrm{zn})$ & $10-75$ \\
\hline
\end{tabular}

The level of the metals found in both the dried and un-dried tapioca samples is above these limits. Above all there is threat of lead poisoning. Lead can easily cross the placenta and damage the foetal brain and may also cause autoimmunity leading to diseases such as rheumatoid arthritis, diseases of kidney, nervous and circulatory system [9]. Only cadmium level is below the permissible maximum limit of heavy metal concentration.

\section{Conclusion and Recommendation}

This study reveals that there is a high level of contamination in samples probably due to the gas flare. All heavy metals showed higher values in the dried tapioca than the un-dried tapioca. This obviously means the dried tapioca got contaminated from the gas flare. Though, this level of contamination is still below WHO standard values for some metals.

Drying tapioca with oil gas flare is not safe because it leads to the contamination of the product with heavy metals and other chemicals that come out of the gas flare.These pose various health risks to the consumer especially the very young children, pregnant women and immunocompromised individuals. It is therefore important that alternative method of drying tapioca be used. These may include sun drying or use of ovens.

\section{References}

[1] Chijioke, E. Gas flares on companies and polities in Nigeria Ebola Scourge Time magazine. May 29, 1995 Ps 50-53.

[2] William P.C and Barbara W.S Environmental science. A global concern sixth edition mackraw -Hil companiesInc.London, 2001 pp 39

[3] Ababio O.Y New school chemistry for senior secondary school. Third edition African publishers Ltd 2005 pp 104-120.

[4] Mac Donald, M, Chadwick, M. and Aslanian G. The environmental management of low-grade fuels 1996pp 50-55.

[5] Splender D, and Sexton, K. Air pollution A public health perspective science 1983221 (4605): 11

[6] Strosher MInvestigation of flare gas emissions is Alberta in energy utilities Board and the CanadianAssociation of petroleum producers 1996.

[7] Sonibare, J.A and Akeredolu F.A, Environmental degradation potential of valural gas flares in upstream petroleum operation, Niger delta, Nigeria 2005 56(3), 125-135.

[8] Godifeld, M. Herzstein J, Jackson, R.J, and Schenker M.B Environmental medicine 1995 pp 603.

[9] Casarett and Doull Heavy metals and health world resources institute, Washington 1996.

[10] Manahan, S.E, Environmental chemistry, $6^{\text {th }}$ edition. Lewis publishing, London, 1994 ISBN.1 56670- 088-4

[11] WHO Guidelines for Drinking water Quality Vol. 1, 1994 World Health Organization, Switzerland, Geneva.

[12] Idodo Umeh College Biology Idodo umeh publisher Ltd, Benin City 2004. 